\title{
Incidence of Sickle Cell Anaemia and Thalassaemia in Central India
}

\author{
Bhaskar P. Urade \\ Department of Anthropology, University of Pune, Pune, India. \\ Email: druradebp@gmail.com
}

Received June 25 ${ }^{\text {th }}, 2012$; revised August $13^{\text {th }}, 2012$; accepted August $26^{\text {th }}, 2012$

\begin{abstract}
Haemoglobinopathies are group of diseases characterized by abnormalities both quantitative and qualitative in the synthesis of haemoglobin. Haemoglobinopathies consist of sickle cell anaemia (SCA), thalassaemia $\left(\beta^{\mathrm{T}}\right)$ and variant haemoglobins. In India, they are responsible for the largest number of genetic disorders and hence are of great public health hazardous. In India major concerned haemoglobinopathic disorders are sickle cell anaemia and $\beta$-thalassaemia. Of the several abnormal haemoglobin molecules, four which are widely prevalent in India include: $\mathrm{HbS}, \mathrm{Hb} \beta^{\mathrm{T}}, \mathrm{HbE}$ and $\mathrm{HbD}$. Examination of 6463 individuals showed high incidences for haemoglobin variants, $\mathrm{HbS}$ and $\mathrm{Hb} \beta^{\mathrm{T}}$ in different ethnic groups, the frequency being varies from $0 \%-20 \%$ and $0 \%-9 \%$ respectively. The frequency of $\mathrm{HbS}$ in Brahmins is $4.17 \%$, in Kalar 5.41\%, in Rajput 2.04\%, in Muslims 3.73\% in Maratha 2.08\% in Bania $9.09 \%$ while in Teli it is $3.65 \%$. Among the Scheduled castes and Nomadic tribal groups $\mathrm{HbS}$ ranges from $1 \%-12 \%$; in backward caste categories it varies from 3\% - 16\%; while in Scheduled tribes it ranges from $0 \%-20 \%$. The high magnitude of sickle cell trait has been noticed in the Pardhan (20.31\%) followed by the Marar (16.10\%), the Dhiwar (11.90\%), the Gond (11.89\%), the Mahar (11.81\%) and the Bania (9.90\%). A considerable high frequency $(9.27 \%)$ of $\beta$-thalassaemia has been observed among the Sindhi population. Sporadic occurrence of $\mathrm{Hb} \beta^{\mathrm{T}}$ and $\mathrm{HbD}$ among other communities suggested the gradual spread of the genes into the region. The present findings in 11 communities with the thalassaemia syndrome suggest that the $\beta$-thalassaemia is accompanied by raised level of $\mathrm{HbA}_{2}$. Unusual greater mean RBC and WBC suggest the high concentration of hypochromic microcytosis in anaemia. The mean MCV and MCH in $\mathrm{Hb} \beta^{\mathrm{T}}$ and $\mathrm{HbD}$ are much lower than the normal ranges compared to HbS. The mean MCHC is much lower in $\mathrm{Hb} \beta^{\mathrm{T}}, \mathrm{HbDD}$ and $\mathrm{HbS}$ than the normal range. The cumulative gene frequency of haemoglobinopathies in India is $4.2 \%$. With a population of over 1 billion and a birth rate of 28 per 1000, there are over 42 million carriers and over 12,000 infants are born each year with a major and clinical significant haemoglobinopathy. Out of these, clinically significant sickle cell anaemia and $\beta$-thalassaemic disorders account for almost equal numbers.
\end{abstract}

Keywords: Haemoglobinopathies; Sickle Cell Anaemia; Thalassaemia; Central India; Prevention; Management

\section{Introduction}

The haemoglobinopathies-sickle cell anaemia, thalassaemia and other abnormal haemoglobins contribute to genetic diseases and imbalance health profile of a nation in general and Vidarbha region in particular. The haemoglobinopathies are a group of inherited conditions that result in the synthesis of either a globins chain with an abnormal structure or reduced synthesis of a globins chain with normal structure leading to chain imbalance. The inherited disorders of haemoglobin are prevalent largely in tropical countries including India. The inherited genetic diseases of haemoglobin are controlled by a single gene that transmits from parents to offspring from one generation to another affecting millions of people throughout the world. Sickle cell anaemia (SCA) and thalassaemia $\left(\beta^{\mathrm{T}}\right)$ are such genetic disorders caused by point mutation, which are of major concern from the point of view of public health policy. Haemoglobin, a component of red blood cells, carries oxygen from the lungs to different body organs and tissues and brings carbon dioxide back to the lungs.

For the first time the presence of Sickle cell gene $(\mathrm{HbS})$ in India was detected in Irula boy in Nilgiri hills in 1952 [1]. This deleterious gene was later on found in many parts of the country. Linus Pualing and his co-workers in 1950 obtained abnormal haemoglobin by electrophoresis in which the proteins with the same molecular weight but different charges migrate at different rates. J. Ingram in 1957 obtained the molecular change in the haemoglobin molecule of sickle cell anaemia.

Pattern of Inheritance 

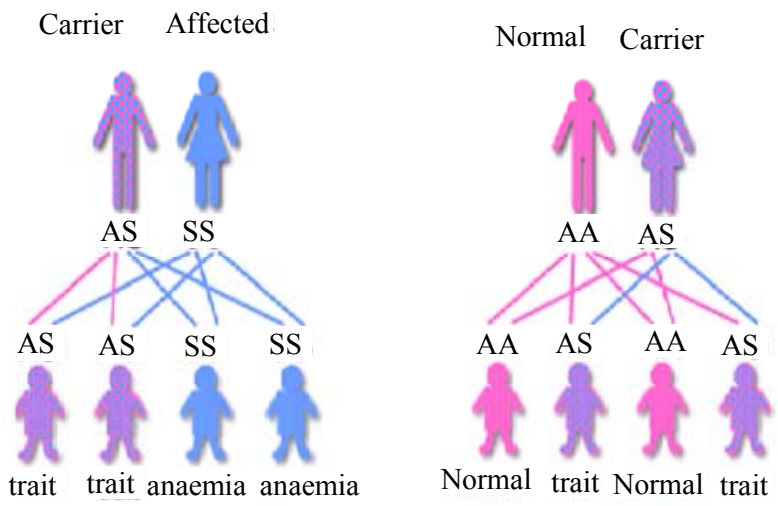

At present about 5 percents of the world's population are carriers of a potentially pathological haemoglobin gene (heterozygote condition). Every year about 300,000 infants worldwide are born with thalassaemia syndrome (30 percents) and sickle cell anaemia (70 percents). Globally, the percentage of carriers of thalassaemia is greater than that of carriers of SCA, but because of the high frequency of the sickle cell gene in certain regions the number of affected birth is higher than with thalassaemia. While the general incidence of $\beta$-thalassaemia trait and sickle cell haemoglobinopathy varies between 3 and 17 percents and 1 and 44 percents respectively, because of high consanguinity and caste and area endogamy some communities show high incidence making the disease a major public and genetic health problem in India [2,3]. Earlier reports show a very high frequency of sickle cell trait ( $>20$ percents) among the Mahar, Kurmi, Panka, Otkar, Pardhan, Pawara, Bhil etc. [4-20]. $\beta$-thalassaemia is a major monogenic single gene disorder resulting from a reduced or absent synthesis of $\beta$-globin chain. This mutant gene is common in communities like, Sindhi, Parsee and Lohana and different ethnic groups of Punjabi, Bengali, Gujarati etc. [21-24]. There are five haplotypes which are responsible for SCA namely, Senegal, Bantu, Benin, Asian and Camroon across the world.

\section{Material and Method}

A systematic mass screening camps were carried out in various schools and at the community level during which 6463 individuals comprising 3468 males and 2995 females from four districts of Vidarbha region were screened for haemoglobin $\mathrm{S}$ and haemoglobin $\beta^{\mathrm{T}}$ using solutions of qualitative solubility test and NESTROFT respectively. Figure 1(a) shows the area from where the data have been collected. Necessary consents as prerequisite were obtained from individuals before subjecting them to the tests. $20 \mu \mathrm{l}$ blood samples were drawn from finger prick for each test and mixed thoroughly with solutions. Result for haemoglobin $\mathrm{S}$ variant was noted down after 3 minutes while for haemoglobin $\beta$-variant it was taken after about 20 - 25 minutes. The sample with turbidity and opaque was considered positive for sickle cell and thalassaemia [25]. $2 \mathrm{ml}$ intravenous blood sample was drawn in B.D. vacutainer and brought to the DNA lab at CRC, Nagpur for further analysis. Haematological indices were measured using calibrated ERMA particle counter.

Laboratory investigations were carried out following standard procedure as described by Dacie and Lewis [25]. All the samples were subjected to haemoglobin electrophoresis using cellulose acetate membrane in alkaline TEB buffer at $\mathrm{pH} 8.9$ for pattern confirmation. The known samples (control) of $\mathrm{HbS}$ and $\mathrm{Hb} \beta^{\mathrm{T}}$ along with present samples were run for electrophoresis. $A_{2}$ fraction of adult haemoglobin was estimated by elution method of $413 \mathrm{~nm}$ using spectrophotometer as well as HPCL. Figure 1(b) shows the mobility of pattern for different haemoglobin variants. A value of more than 3.5 percents for A2 was considered as the cut off point for determination of $\beta$-thalassaemia trait. Foetal haemoglobin was estimated by the method of Betke et al. [26].

Only male samples were subjected to for $\mathrm{G}_{6} \mathrm{PD}$ deficiency status by florescent spottest [27].

\section{Results}

Total samples of 6463 individuals have been screened for sickle cell anaemia and thalassaemia with the qualitative solubility test and NESTROFT respectively. Out of which 374 (5.78 percents) and 145 (2.24 percents) individuals were shown to be positive for $\mathrm{HbS}$ for $\mathrm{Hb} \beta^{\mathrm{T}}$ respectively.

Table 1 portrays the frequency for $\mathrm{HbS}$ and $\mathrm{Hb} \beta^{\mathrm{T}}$ varies from $0.16-33.33$ percents and $0.72-9.27$ percents respectively. A very high frequency of $\mathrm{HbS}$ is recorded among the Pardeshi (25 percents) followed by the Pardhan (20.31 percents). A moderate frequency has been seen among the Dhiwar and the Bania (9.09 per-

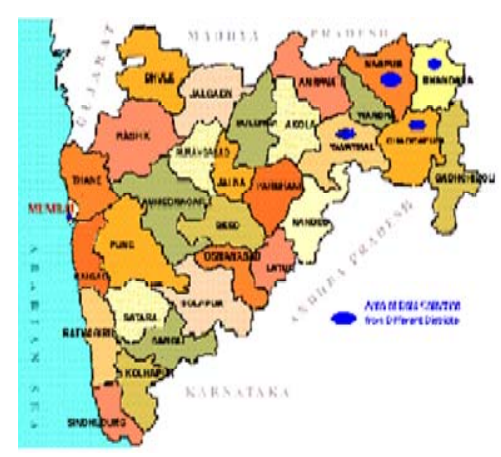

(a)

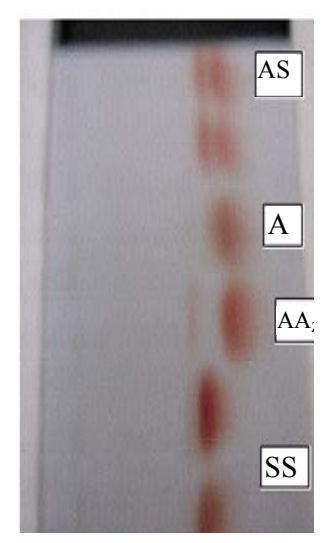

(b)
Figure 1. (a) Map of Maharashtra showing study area; (b) Position of $\mathrm{Hb}$ variants. 
Table 1. Profile of Haemoglobinopathies in Vidarbha region of Maharashtra.

\begin{tabular}{|c|c|c|c|c|c|c|c|c|c|c|c|c|c|}
\hline \multirow{2}{*}{ Community } & \multirow{2}{*}{ No. } & \multicolumn{2}{|c|}{$\mathrm{HbAA}$} & \multicolumn{2}{|c|}{$\mathrm{HbAS}$} & \multicolumn{2}{|c|}{$\mathrm{HbSS}$} & \multicolumn{2}{|c|}{$\beta$-thal } & \multicolumn{2}{|c|}{ HbAD } & \multirow{2}{*}{$\begin{array}{c}\text { HbDD } \\
\text { No. }\end{array}$} & \multirow{2}{*}{$\begin{array}{l}\mathrm{HbF} \\
\text { No. }\end{array}$} \\
\hline & & M & $\mathrm{F}$ & No. & $\%$ & No. & $\%$ & No. & $\%$ & No. & $\%$ & & \\
\hline Kunbi & 185 & 77 & 99 & 9 & 4.86 & - & - & - & - & - & - & - & - \\
\hline Teli & 329 & 177 & 140 & 12 & 3.65 & - & - & - & - & - & - & - & - \\
\hline Halba & 139 & 86 & 49 & 2 & 1.44 & - & - & 1 & 0.72 & 1 & 0.72 & - & - \\
\hline Gond & 230 & 103 & 99 & 27 & 11.74 & - & - & 1 & 0.43 & - & - & - & - \\
\hline Gowari & 55 & 29 & 22 & 4 & 7.27 & - & - & - & - & - & - & - & - \\
\hline Marar/Mali & 118 & 40 & 59 & 19 & 16.10 & - & - & - & - & - & - & - & - \\
\hline Maratha kunbi & 48 & 17 & 30 & 1 & 2.08 & - & - & - & - & - & - & - & - \\
\hline Dange kunbi & 18 & 8 & 9 & 1 & 5.56 & - & - & - & - & - & - & - & - \\
\hline Kalar & 111 & 56 & 49 & 6 & 5.41 & - & - & - & - & - & - & - & - \\
\hline Brahmin & 144 & 89 & 49 & 6 & 4.17 & - & - & - & - & - & - & - & - \\
\hline Tirale kunbi & 134 & 75 & 52 & 6 & 4.48 & - & - & 1 & 0.75 & - & - & - & - \\
\hline Khaire kunbi & 246 & 94 & 129 & 23 & 9.35 & - & - & - & - & - & - & - & - \\
\hline Zade kunbi & 13 & 7 & 5 & 1 & 7.69 & - & - & - & - & - & - & - & - \\
\hline Chambhar & 54 & 28 & 25 & 1 & 1.85 & - & - & - & - & - & - & - & - \\
\hline Dhangar & 43 & 25 & 17 & 1 & 2.33 & - & - & 1 & 2.33 & - & - & - & 1 \\
\hline Pardhan & 64 & 22 & 28 & 13 & 20.31 & 1 & 1.56 & - & - & - & - & - & 1 \\
\hline Kohali & 37 & 16 & 20 & 1 & 2.70 & - & - & - & - & - & - & - & - \\
\hline Bania & 11 & 8 & 2 & 1 & 9.09 & - & - & - & - & - & - & - & - \\
\hline Banjara & 17 & 10 & 4 & 1 & 5.88 & 1 & 5.88 & 1 & 5.88 & - & - & - & - \\
\hline Muslim & 161 & 117 & 38 & 6 & 3.73 & - & - & - & - & - & - & - & - \\
\hline Mehetar & 62 & 29 & 32 & 1 & 1.61 & - & - & - & - & - & - & - & - \\
\hline Madgi & 40 & 21 & 15 & 4 & 10.0 & - & - & - & - & - & - & - & - \\
\hline Dhobi & 43 & 24 & 15 & 2 & 4.65 & - & - & 2 & 4.65 & - & - & - & - \\
\hline Rajput & 49 & 28 & 18 & 1 & 2.04 & - & - & 1 & 2.04 & - & - & 1 & - \\
\hline Powar & 113 & 57 & 52 & 2 & 1.77 & - & - & 4 & 3.54 & - & - & - & 2 \\
\hline Sutar & 30 & 14 & 16 & - & - & - & - & - & - & - & - & - & - \\
\hline Lohar & 59 & 26 & 32 & 1 & 1.69 & - & - & - & - & - & - & - & - \\
\hline Dhanoje kunbi & 2 & - & 2 & - & - & - & - & - & - & - & - & - & - \\
\hline Lewa kunbi & 4 & 1 & 3 & - & - & - & - & - & - & - & - & - & - \\
\hline Lonare kunbi & 3 & 2 & 1 & - & - & - & - & - & - & - & - & - & - \\
\hline Katia & 2 & - & 1 & 1 & 50.0 & - & - & - & - & - & - & - & - \\
\hline Navi & 17 & 12 & 5 & - & - & - & - & - & - & - & - & - & - \\
\hline
\end{tabular}




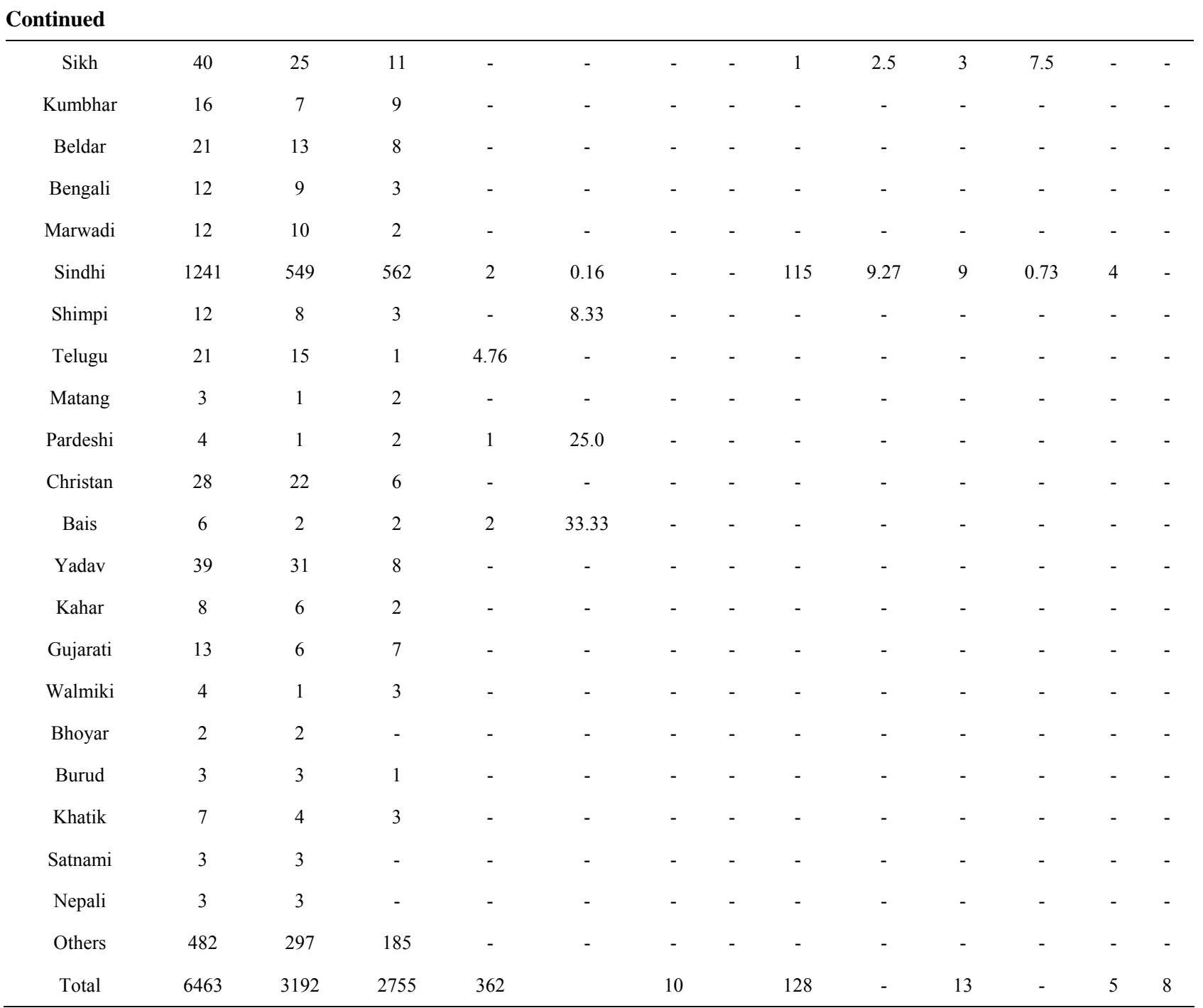

cents each), the Gond (11.74 percents each), the Mahar (11.81 percents), the Shimpi (8.33 percents), the Zade kunbi(7.69 percents), the Madgi (7.5 percents) and the Gowari (7.27 percents). An appreciable frequency of $\mathrm{HbS}$ has seen among the Banjara (5.88 percents), the Khaire kunbi (9.35 percents), the Dange kunbi (5.56 percents), the Kalar (5.41 percents), the Kunbi (4.86 percents), the Telugu (4.76 percents), the Tirale kunbi (4.48 percents), the Bawane kunbi (4.35 percents), the Brahmin (4.17 percents), the Muslim (3.73 percents) and the Teli (3.65 percents). However, in some of the sub-group and castes no abnormality of any $\mathrm{Hb}$ variant is seen. Since these cases represent the local population structure, they reflect the magnitude and vulnerability of the haemoglobinopathy in the population and the region (Figure 2). Most of the cases of haemoglobinopathy, in general are detected when they come forward casually find their status.

From the spectrum of haemoglobinopathies it has been observed that the sickle cell trait is the most common haemoglobinopathy ( 5.6 percents) followed by $\beta$-thalassaemia carrier (2.01 percents), sickle cell disease $(0.15$ percents) $\mathrm{HbD}$ trait (0.19 percents), HbD homozygous (0.08 percents) and $\operatorname{HbSF} \beta^{\mathrm{T}}(0.12$ percents $)$ were encountered.

The present study shows a moderate frequency of $\beta$-thalassaemia (9.27 percents) among the Sindhi. Sporadic occurrence of $\beta$-thalassaemia has also been found among other Hindu caste population in Vidarbha region (Figure 3). However, a very high frequency ( 8 - 17 percents) of the gene $\mathrm{Hb} \beta^{\mathrm{T}}$ has been reported among the Sindhi population of Nagpur [13,23].

The mean of all the haemotological parameters showed significantly lower levels and increased level of fetal haemoglobin $(\mathrm{HbF})$ and $\mathrm{A}_{2}$. The percent of $\mathrm{A}_{2}$ ranges from 3.52 - 16.52. The mean $\mathrm{WBC}$ in SCT shows higher than the mean values for $\beta$-thalassaemia minor, $\mathrm{HbAD}$ and HbDD. The mean RBC of SCT shows lesser 


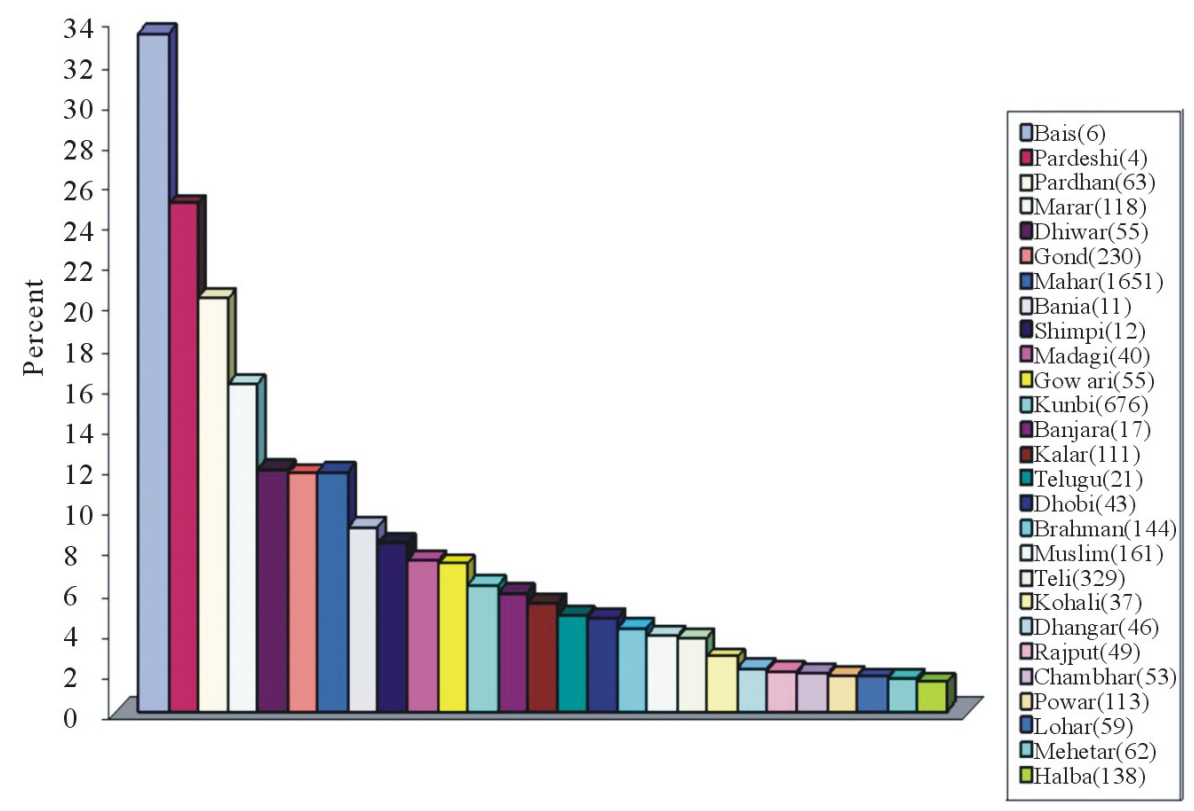

Figure 2. Community-wise frequency distribution of SCT in Vidarbha.

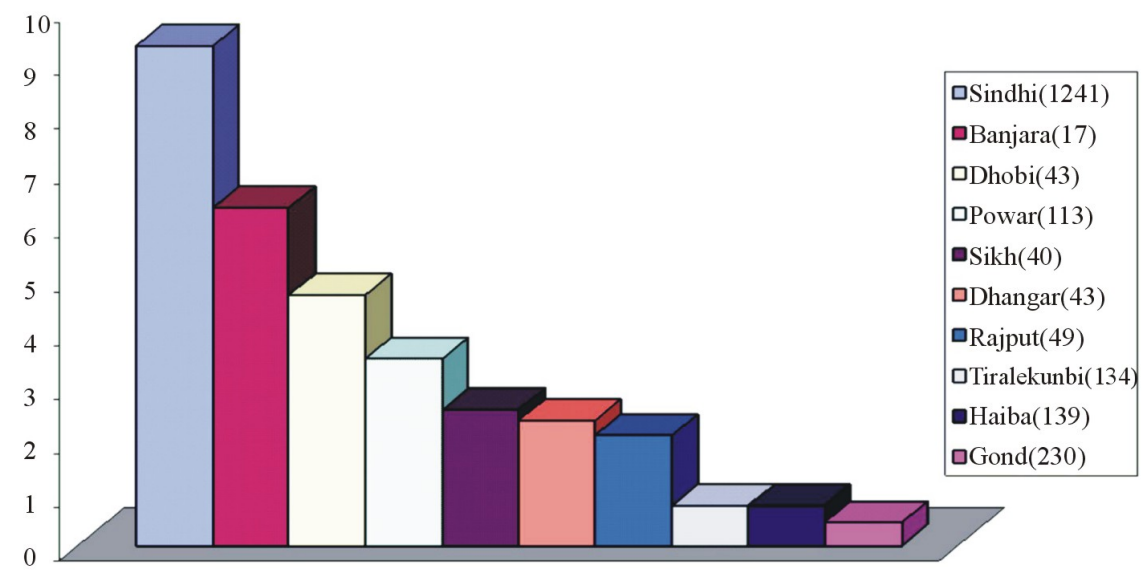

Figure 3. Community-wise frequency distribution of $\beta$-thalassaemia in Vidarbha region.

value than the mean for $\beta$-thalassaemia minor and HbDD. The mean values of $\mathrm{Hb}, \mathrm{MCV}, \mathrm{MCH}$ and $\mathrm{MCHC}$ among SCT of both male and female shows higher frequencies than their $\beta$-thalassaemia minor counterparts (Figures 4 $\& 5)$. However, the mean of all the above-mentioned haemotological parameters has been found much below than their normal ranges. The red cell count is relatively higher in relation to the haemoglobin and $\mathrm{MCH}$ in $\beta$-thalassaemia minor.

Evidently the $\mathrm{HbS}$ gene is prevalent in general castes like Brahman, Rajput, Kalar, Bania and Sindhi. Balgir [28] reported a very high frequency of $\beta$-thalassaemia in Khandayat, Brahmin and the Karan and $\mathrm{HbS}$ is no exception in these populations. Sinha et al. [29] reported the presence of $\mathrm{HbS}$ and $\mathrm{Hb} \beta^{\mathrm{T}}$ among the Bramin and Muslim. The present findings are in conformity with the above cited findings. Bhasin et al. [30] argued that the findings of $\mathrm{HbS}$ and $\mathrm{Hb} \beta^{\mathrm{T}}$ reported earlier elsewhere in India where the haemoglobinopathy is stated to be confined only in Scheduled tribes and Scheduled castes and that the general castes are not affected. This hypothetical assumptions lead to a major controversy in the field of haemoglobinopathies as the genetic disorders are of public health concerned rather than any ethnic specific.

It is apparent that the $\mathrm{HbS}$ gene has spread all over the region irrespective of caste or community. $\beta$-thalassaemia once it was stated to be confined to the Sindhi and Sikh, who migrated from Sindh region of Pakistan, has been detected in other communities. It is interesting to know that in all 11 communities among whom the $\beta$ thalassaemia has been found, were interviewed and said that no inter-caste marriages were taken place at least for 


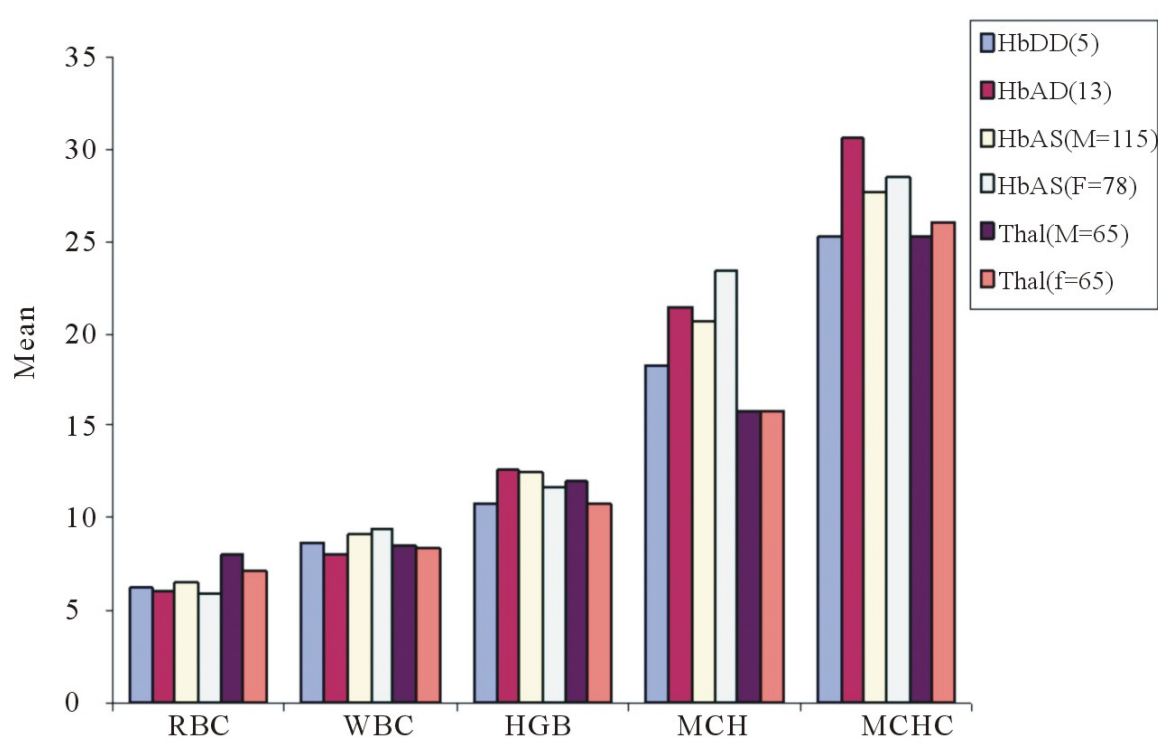

Figure 4. Distribution of mean of cell morphology.

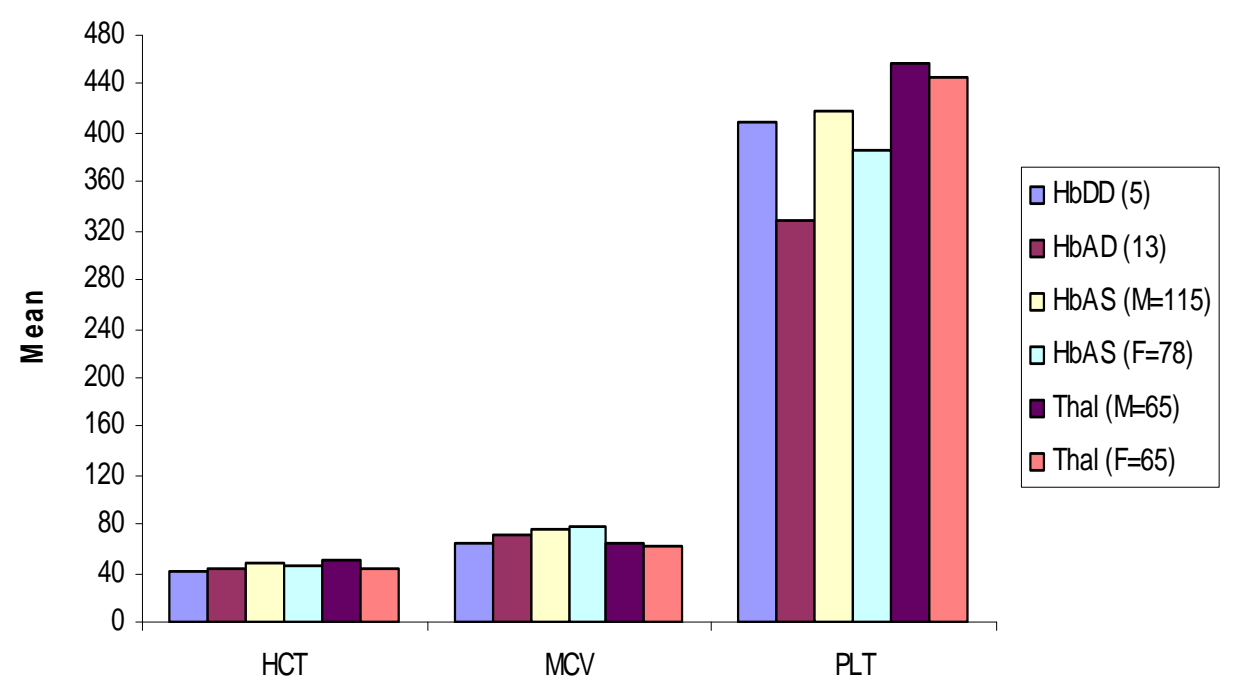

Figure 5. Distribution of mean of cell morphology.

3- 4 generations except 2 - 3 cases of the Sindhi. The presence of $\mathrm{HbD}^{\text {Punjab }}$ gene among the Sindhi, Punjabi, Halba and the Rajput and absence in other communities is a clear indication that there is no spread of $\mathrm{HbD}^{\text {Punjab }}$ in the region.

Ironically, the majority of the cases (50.26 percents) of SCT have been found under childhood period (up to 15 yrs) followed by a reproductive age group (16 - 45 yrs; 46.63 percents). While the individuals of $\operatorname{HbAD}(68.75$ percents) and $\beta$-thalassaemia carrier (53.12 percents) shows higher frequency of reproductive age. Only a few cases have been detected for $\mathrm{HbS}$ and $\mathrm{Hb} \beta^{\mathrm{T}}$ variants after reproductive age.

G6PD deficiency has been 10.94 percents among the $\beta$-thalassaemia (Sindhi population) and shows a significant association with thalassaemia whereas it was completely absent in sickle cell anaemia.

\section{Discussion}

The sickle cell anaemia and thalassaemia are the most severe form of genetic disorders and hence are of great importance to be dealt with from public health point of view in India. These two forms of haemoglobin variants prevalent at higher magnitude pose a great threat to population imbalance. Therefore, these inherited abnormalities of haemoglobin synthesis are the most serious public health problem in central India in particular and in 
India in general reflecting the genetic heterogeneity of the population.

The earlier researchers have shown a complete absence of gene $\mathrm{HbS}$ in Muslims [31-34]. On the contrary to this, the present findings show the presence of gene $\mathrm{HbS}$ among the Muslim (3.73 percents) and is in agreement with earlier findings $[28,29]$. A very high frequency among the Pardhan was reported $[9,11,12,35]$. The present findings are in agreement with the findings [4] where they had reported a very high frequency of $\mathrm{HbS}$ among the Mahar and the Kunbi. Sickle cell is prevalent in Maharashtra, Madya Pradesh, Orissa, Andhra Pradesh, Gujarat, Tamil Nadu, Karnataka, Kerala and Uttar Pradesh [36]. The HbS gene is prevalent among the general caste including Brahmins and is in conformity with the findings reported $[28,29]$.

The presence of the deleterious gene $\mathrm{HbS}$ in some groups and the complete absence in some groups indicates that the independent mutation might have taken place during early life of human being. It is evident from the literature that the several ethnic groups with varied genetic elements have been assimilated into the mainstream, resulting in population diversity with the passage of time [37]. This situation leads to the parallel divergence of sub groups of the same community that the one group with the deleterious gene emerged while another group of the same ethnic elements evolved unaffected during the course of time. Initially the mutation might have originated at first and gradually reached a high frequency in these populations. Sometime migration may also one of the reasons to carry mutant allele into other population, which ultimately reached a high frequency. The subdivision of the population of India by geographic, linguistic, religious caste and other barriers has resulted in the existence and perpetuation of thousands of distinct highly inbred communities [38]. This remarkable genetic heterogeneity is a distinctive feature of the Indian population accounts for uneven and variable distribution of the haemoglobinopathies [39]. Diffusion of HbS mutation from the Middle East region to India by Arab or Muslim expansion was proposed by Livingstone [40]. In most cases, $\mathrm{HbS}$ mutation in the Middle East and in India shares a common haplotype but the high prevalence of $\mathrm{HbS}$ among the tribal and scheduled caste populations of India and its relatively less among the Muslims does not convince the suggestion.

A considerable high level of $\mathrm{HbF}$ in few cases of sickle cell patient and $\beta$-thalassaemia carrier provides a protective mechanism in ameliorating the quality of life. A few incidences of splenomegaly have been observed in sickle cell patient, $\operatorname{HbS} \beta^{\mathrm{T}}$ and $\beta$-thalassaemia major. The persistence splenomegaly was greater in $\operatorname{HbSF} \beta^{\mathrm{T}}$ patients probably related to the raised $\mathrm{HbF}$ level found in Indian. Higgs et al. [41] reported a significantly greater persis- tence of splenomegaly in Jamaican. The effect of $\alpha$-thalassaemia is not large enough to be noticeable in Indian populations [42] but this test was not done in the present study.

The spread of $\mathrm{Hb} \beta$ gene in the region is due to gene flow or migration of people from north-west pre-independent India ie, Sindh region of Pakistan. It is evident from the present findings that the $\beta$ haemoglobin is in abundance in endemic form in the present population from where they had spread to other part of the central India.

It is interesting to note that rapid proliferations of abnormal haemoglobins $\mathrm{S}$ and $\mathrm{Hb} \beta^{\mathrm{T}}$ in central India is due to castes and area endogamy and lack of medical facilities. These many aspects are the root causes for increaseing complexions of SCD and $\beta$-thalassaemia in central India.

The $\mathrm{HbS} \beta$-thalassaemia patients had more severe disease with lower $\mathrm{Hb}$ level, MCV and $\mathrm{MCH}$ than their counterparts having HbSS. The red cell count was relatively higher among $\mathrm{HbS} \beta$ patients in relation of the haemoglobin and $\mathrm{MCH}$ in carriers of the thalassaemia may be due to production of extra microcytes. In the present study the detection of $\mathrm{HbAD}$ (5 percents) in the Sikh is in agreement with the earlier reports $[21,24,43]$.

\section{Conclusions}

Haemoglobinopathies are the most common monogenic disorder affecting the millions of population worldwide. The geographical distribution of $\mathrm{HbS}$ and $\mathrm{Hb} \beta^{\mathrm{T}}$ variants in India is not uniform as the prevalence varies from 2 22 percent and $1-15$ percent respectively in different region of the country. In central India the incidence of $\beta$-thalassaemia has been mainly attributed to its high prevalence in the migrant population of Sindhi origin. Screening of healthy population is required to determine the carrier rates and gene frequencies in this region. Because of the complications associated with haemoglobinopathies and frequent health crisis these genetic disorders are becoming a growing health care problem in all regions of the developing country. The urgent attention and need of the hour is to launch community based mass screening programme at large level to target the high risk population so that implementation and monitoring can be done to reduce the prevalence of haemoglobinopathies in the country.

The misbelieve/wrong notions that has been deeply rooted in the society is that, the presence of sickle cell gene among the lower castes is due to food habits as the people used to eat the flesh of dead animals during earlier days. Historically, the man used to eat animal flesh and tubers for his survival when he evolved until he learnt to produce food. Each and everybody were solely 
dependent upon the nature, sharing a common platform and consumed same thing more or less equally whatever was available during that time. So it is worth mentioning here that every small group of population has something or the other genetic disorder as there is no association between caste or creed and disease. Therefore it is inappropriate to say that SCA is confined to the lower caste and tribal groups. Earlier researchers were mostly confined to tribal groups and hence they did not have any other option but to write about scheduled tribe. From the present study it may be stated that the presence of $\mathrm{HbS}$ among higher communities pave the way of transmitting this gene in to lower castes during ancient period as the higher caste people used to sexually exploit socially and economically backward populations. To suppress this fact, there was planned and a thoughtful view of earlier researchers $[10,44]$ who stigmatised the Mahar from central India with the high rate of sickling so that the label of high SCA could remains with them. With the advent of modern technology it has been cleared now that the earlier food habit has nothing to do with the occurrence of sickle cell or thalassaemia in man. Occurrence of deleterious gene $\mathrm{HbS}$ and $\mathrm{Hb} \beta^{\mathrm{T}}$ among the people of different communities is due to alteration at the molecular level in the genetic material (DNA) what is called mutation. Sickle cell anaemia and thalassaemia are the best examples of point mutation as these disorders are caused by a single gene which is transmitted through parents to offspring from generation to generations. And this mutation has taken place independently in different communities in different areas across the world during the course of human evolution.

In present study the presence of $\mathrm{HbS}$ gene in almost all castes and communities demonstrate that sickle cell anaemia is no longer confined to specific ethnic groups; instead it is widely distributed in all tribal, scheduled caste, backward and higher caste populations' native to this region. Similarly, sporadic occurrence of $\mathrm{Hb} \beta^{\mathrm{T}}, \mathrm{HbD}$ in the present study suggests the spread of $\mathrm{Hb} \beta^{\mathrm{T}}$ well beyond the Sindh and Punjab regions to central India. The high magnitude of $\mathrm{HbS}$ and $\beta^{\mathrm{T}}$ appears to contribute significantly to the load of haemoglobinopathies in this region which ultimately going to be a great challenge imbalancing the genetic constitution and threat to these populations in this region. Since many of the sicklers live up to $40-42$ years with active reproductive life and carriers lead a normal life like healthy ones, they enhance the chance of propagation of deleterious genes of sickle cell anaemia, thalassaemia and other abnormal haemoglobin genes for generations together. It is not unrealistic to state that the presence of $\mathrm{HbS}, \beta^{\mathrm{T}}$ and $\mathrm{HbD}$ in hitherto unreported communities from this region is due to of lack of research, under-diagnosis due to suspicion, prevailing bias and prejudices, stigma, complexity, defaming attitude, lack of awareness and absence of diagnostic facilities at prenatal stage.

In Maharashtra, the incidence of $\mathrm{Hb} \beta^{\mathrm{T}}$ has been mainly attributed to its high prevalence in the migrant population of Sindhi. The sporadic occurrence of $\operatorname{Hb} \beta^{\mathrm{T}}$ among other communities is the indication of either gradual spread of $\beta$-gene due to hybridization or due to independent mutation during the course of evolution which needs further indepth research at the molecular level to decipher the reason.

The most effective approach to tackle the menace of haemoglobinopathies, it is essential to offering genetic counselling, proper health education, sensitization to the individual concern, prenatal diagnosis and selective termination of pregnancy of the affected foetus are the remedial measures for prevention and management of haemoglobinopathies in India to see better tomorrow and healthy nation.

\subsection{Prevention}

1) Identification of groups at high risk through mass screening at the community level.

2) Carrier couples detected are informed of the genetic risk and advice for prenatal diagnosis.

3) Screening and counselling can lead to a significant reduction in affected births.

4) Strategy for prevention-provision of prenatal diagnosis for risk couple and screening of People of premarital $/$ reproductive age.

5) Genetic counselling is essential to protect the autonomy of the individual. It should be sensitive to the cultural, religious and ethical views of the individual.

\subsection{Management}

1) Public education, genetics, detection of genetic risk the community, family history and premarital genetic counselling.

2) Nationwide programme for prevention and treatment.

3) A barrier to implementing effective haemoglobinopathy services is lack of awareness about genetic diseases. Improve understanding and awareness at community level.

4) Medical education and training courses should include modules on genetic counselling, the application of genetics to public health and the associated ethical, legal and social issues.

5) Due to lack of sufficient data on the epidemiology of haemoglobinopathies, research and surveillance are important for planning and evaluation of intervention.

6) Heamoglobinopathies are becoming challenging task to introduce genetic approaches to control other chronic 
childhood diseases. Before formulating are effective programme, health authorities, health professionals and expert should perceive haemoglobin disorder as a public health problem.

\section{Acknowledgements}

Author expresses his deep concern and gratitude to the Director, Anthropological Survey of India, and Govt. of India for sanctioning the project-haemoglobinopathies in central India, Prof. C.S. Singhrol, Prof. Moyna Chakravarty, and Prof. Anjali Kurane for offering their valuable suggestions, people who donated blood and colleagues who helped in analyzing blood samples in DNA Lab of ASI, Nagpur.

\section{REFERENCES}

[1] H. Lehman and M. Cutbush, "Sickle Cell Trait in Southern India," British Medical Journal, Vol. 1, No. 4755, 1952, pp. 404-405. doi:10.1136/bmj.1.4755.404

[2] R. S. Balgir, "The Burden of Haemoglobinopathies in India and the Challenges Ahead," Current Science, Vol. 79, 2000, pp. 1536-1547.

[3] R. S. Balgir, "The Genetic Burden of Haemoglobinopathies with Special Reference to Community Health in India and the Challenges Ahead," Indian Journal of Hematology and Blood Transfusion, Vol. 20, 2002, pp. 2-7.

[4] B. N. Shukla and B. R. Solanki, "Sickle Cell Anaemia in Central India," The Lancet, Vol. 271, No. 7015, 1958, p. 297. doi:10.1016/S0140-6736(58)91035-3

[5] V. V. Deshmukh, "Deficiency of Erythrocyte Glucose-6Phosphate Dehydrogenase and Sickle-Cell Trait: A Survey at Aurangabad, Maharashtra," Indian Journal of Medical Research, Vol. 56, No. 6, 1968, pp. 821-825.

[6] L. A. Ghatge, "Haemoglobins in Kurmi, Pradhan, PK Community of Madhya Pradesh," Journal of the Medical Research, Vol. 66, No. 2, 1977, p. 260.

[7] R. S. Negi, "Population Dynamics of Sickle Cell Traits Distribution in India," Ph.D. Thesis (Unpublished), University of Calcutta, Calcutta, 1976.

[8] S. L. Kate, "Health Problem of Tribal Population Groups from the State of Maharashtra," Indian Journal of Medical Science, Vol. 55, No. 2, 2001, pp. 99-108.

[9] N. M. Blake, A. Ramesh, M. Vijaykumar, J. S. Murthy and K. K. Bhatia, "Genetic Studies on Some Tribes of the Telangana Region, Andhra Pradesh, India," Acta Anthropogenetica, Vol. 5, No. 1, 1981, pp. 41-56.

[10] S. R. Das, N. Kumar, P. N. Bhattacharjee and D. B. Sastry, "Blood Groups (ABO, MN, \& Rh), ABH Secretion, Sickle Cell, PTC Taste and Colour Blindness in the Mahar of Nagpur," Journal of the Royal Anthropological Institute of Great Britain and Ireland, Vol. 91, No. 2, 1961, pp. 345-355. doi:10.2307/2844419

[11] H. P. Banker, S. L. Kate, G. D. Mokanshi, V. A. Kheedkar and M. A. Phadke, "Distribution of Sickle Cell Haemoglobin among Different Tribal Groups in Maharashtra
State," Indian Journal of Haematology, Vol. 2, 1984, p. 4.

[12] J. D. Goud and P. R. Rao, "Genetic Studies among the Five Tribal Populations of Andhra Pradesh, South India," Anthropologischer Anzeiger, Vol. 37, No. 1, 1979, pp. 1-9.

[13] M. Jain, K. Das, P. B. S. V. Padmanabham, P. Dhar and V. R. Rao, "A1A2BO, Rh (D) Blood Groups and Haemoglobinopathies among Neo-Buddhist (Mahar) of Nagpur City," Man in India, Vol. 84, No. 1-2, 2003, pp. 77-83.

[14] B. P. Urade, "Haemoglobinopathies in Vidarbha Region of Maharashtra," National Conference on Prevention of Beta-Thalassaemia in India, Anthropological Survey of India, Kolkata, 7-9 March 2008.

[15] B. P. Urade and S. K. Mallick, "Incidence of Sickle Cell Anaemia in Chhattisgarh-A Review," National Seminar, School of Studies in Anthropology, Pt. R.S.S. University, Raipur, 2003.

[16] B. P. Urade and S. K. Mallick, "Incidence of Sickle Cell Anaemia among the Mahar of Raipur, Chhattisgarh," National Seminar, School of Studies in Anthropology, Pt. R.S.S. University, Raipur, 25-27 February 2004.

[17] B. P. Urade and M. Chakravarty, "Haemoglobinopathies of Central and North-Eastern India," National Seminar, School of Studies in Anthropology, Pt. R.S.S. University, Raipur, 28-30 November 2006.

[18] B. P. Urade, M. Chakravarty and S. K. Mallick, "Sickle Cell Anaemia-A Genetically Handicap Disease," In: R. K. Pathak, A. K. Sinha, B. G. Banerjee, R. N. Vasishat and C. J. Edwin, Eds., Bio-Social Issues in Health, Northern Book Centre, New Delhi, 2008, pp. 47-55.

[19] B. P. Urade, J. Verma and V. R. Rao, "Haemoglobinopathies in Maharashtra-Current Scenario and Challenges Ahead," National Seminar on Human Genomic and Cultural Diversity at School of Studies in Anthropology, Pt. R.S.S. University, Raipur, 2-4 March 2009.

[20] G. Chakravarty and B. P. Urade, "Haematological Profile in Sickle Cell Anaemia and Thalassaemia Patients in Vidarbha Region of Maharashtra," National Seminar on Human Genomic and Cultural Diversity at School of Studies in Anthropology, Pt. R.S.S. University, Raipur, 2-4 March 2009.

[21] J. K. Siddoo, S. K. Siddoo, W. H. Chase, L. M. Dean and W. H. Perry, "Thalassaemia in Sikhs," Blood, Vol. 11, No. 3, 1956, pp. 197-210.

[22] R. S. Balgir, "Genetic Epidemiology of the Three Predominant Abnormal Haemoglobins in India," Journal of the Associations of Physicians of India, Vol. 44, No. 1, 1996, pp. 5-28.

[23] A. Jawahirani, M. Mamtani, K. Das, V. Rughwani and H. Kulkarni, "Prevalence of $\beta$-Thalassaemia in Subcastes of Indian Sindhi-Results from a Two Phase Survey," Public Health, Vol. 121, No. 3, 2007, pp. 193-198. doi:10.1016/j.puhe.2006.10.017

[24] N. Saha and B. Banerjee, "Incidence of Abnormal Haemoglobins in Punjab," Calcutta Medical Journal, Vol. 62, 1965, pp. 82-86.

[25] J. V. Dacie and S. M. Lewis, "Practical Haematology," Churchill Livingstone, Edinburgh, 1977.

[26] K. Betke, H. R. Marti and I. Schlicht, "Estimation of a 
Small Percentage of Foetal Haemoglobin," Nature, Vol. 184, 1959, pp. 1877-1878. doi:10.1038/1841877a0

[27] K. G. Beutler, J. C. Kaplan, G. W. Lohr, B. Ramot and W. N. Valentine, "International Committee for Standardization in Haematology; Recommended Screening Test G6PD Deficiency," British Journal of Haematology, Vol. 43, No. 3, 1979, pp. 43-46.

[28] R. S. Balgir, "Scenario of Haemoglobin Variants in Central-East Coast of India," Current Science, Vol. 90, No. 12, 2006, pp. 1651-1657.

[29] S. Sinha, A. Kumar, V. Gupta, S. Kumar, V. P. Singh and R. Raman, "Haemoglobinopathies-Thalassaemias and Abnormal Haemoglobins in Eastern Uttar Pradesh and Adjoining Districts of Neighbouring States," Current Science, Vol. 87, No. 6, 2004, pp. 775-780.

[30] M. K. Bhasin, H. Walter and H. Danker-Hopfe, "Glucose6-Phosphate Dehydrogenase Deficiency and Abnormal Haemoglobins (S and E) in People of India," Journal of Human Ecology, Vol. 3, 1994, pp. 131-159.

[31] M. Vijaykumar, K. C. Malhotra, H. Walter, K. Gilbert, P. Landenberg, A. Dannewitz, A. Sorensen, R. Chakraborty, A. P. Reddy and B. N. Mukherjee, "Genetic Studies among the Siddis of Karnataka, India. A Migrant Population from Africa," Zeitschrift fur Morphologie und Anthropologie, Vol. 77, No. 2, 1987, pp. 97-121.

[32] A. C. Gorakshakar, M. S. Sathe, S. R. Shirsat and H. M. Bhatia, "Genetic Studies in Ratnagiri and Sindhudurg Districts of Maharashtra-Incidence of ABO, Rh(D), Ina Antigens, G-6PD Deficiency and Abnormal Haemoglobins," Journal of the Indian Anthropological Society, Vol. 22, 1987, pp. 38-46.

[33] S. M. A. Hakim, A. J. Baxi, V. Balkrishnan, K. V. Kulkarni, S. S. Rao and H. T. Jhala, "Haptoglobin, Transferrin and Abnormal Haemoglobin in Indian Muslims," Indian Journal of Medical Research, Vol. 60, No. 5, 1972, pp. 699-703.

[34] N. R. Saha, L. Kirk, S. Shanbhag, S. R. Joshi and H. M. Bhatia, "Population Genetic Studies in Kerala and the Nilgiris (South West Asia)," Human Heredity, Vol. 26, 1976, pp.175-197. doi:10.1159/000152802
[35] V. R. Rao and H. M. Bhatia, "Quantitative Assessment of $\mathrm{HbS}$ in Sickle Cell Heterozygotes among Some Tribes in Maharashtra," Indian Journal of Medical Research, Vol. 87, 1988, pp. 257-261.

[36] M. B. Agarwal, "The Burden of Haemoglobinopaties in India-Time to Wake Up?" Journal of the Associations of Physicians of India, Vol. 53, 2005, pp. 1017-1018.

[37] R. V. Russel and H. Lal, "Tribes and Castes of the Central Provinces of India," Vol. 4, McMillon Company, London, 1916.

[38] G. M. Brittenham, "Globin Gene Variant and Polymorphism in India," In: W. P. Winter, Ed., Haemoglobin Variants in Human Populations, CRC Press Inc., Florida, Vol. 2, 1988, pp. 79-109.

[39] C. S. Iswad and S. N. Naik, In: H. M. Bhatia and V. R. Rao, Eds., Genetic Atlas and Indian Tribes, ICMR, Bomba, 1986.

[40] F. B. Livingstone, "Who Gave Whom Haemoglobin SThe Use of Restriction Cite Haplotype Variation for the Interpretation of the Evolution of the $\beta^{\mathrm{S}}$ Globin Gene," American Journal of Human Biology, Vol. 1, No. 3, 1989, pp. 289-302. doi:10.1002/ajhb.1310010309

[41] D. R. Higgs, B. E. Aldridge, J. Lamb, J. B. Clegg, D. J. Weatherall, R. H. Hayes, Y. Grandison, Y. Lowrie, K. P. Mason, B. E. Searjeant and G. R. Searjeant, "The Interaction of Alpha Thalassaemia and Homozygous Sickle Cell Disease," The New England Journal of Medicine, Vol. 306, No. 24, 1982, p. 1441. doi:10.1056/NEJM198206173062402

[42] A. E. Kulozik, B. C. Kar, R. K. Satapathy, B. E. Searjeant, G. R. Searjeant and D. J. Weatherall, "Foetal Haemoglobin Levels and $\beta^{\mathrm{S}}$ Globin Haplotypes in an Indian Population with Sickle Cell Disease," Blood, Vol. 69, 1987, p. 1742.

[43] G. W. G. Bird and H. Lehmann, "Haemoglobin D in India," British Medical Journal, Vol. 1, 1956, p. 514. doi:10.1136/bmj.1.4965.514

[44] I. Karve and V. M. Dandekar, "Anthropometric Measurement of Maharashtra, Deccan College Monograph," Series No. 8, 1951. 